\title{
Two types of varicella zoster in one patient
}

\author{
Stephen J. Mounsey
}

Department of Dermatology, University College London Hospitals NHS Foundation Trust, London, UK

\section{Correspondence to} Dr Stephen J. Mounsey, stephen.mounsey@uclh.nhs.uk

Accepted 2 September 2017

\section{DESCRIPTION}

A 79-year-old patient, with a background of chronic lymphocytic leukaemia, presents with herpes zoster (HZ) affecting the left C2/3 dermatome (figure 1). Three days after initial development, a secondary diffuse vesicular papuloblistering rash developed on the trunk,

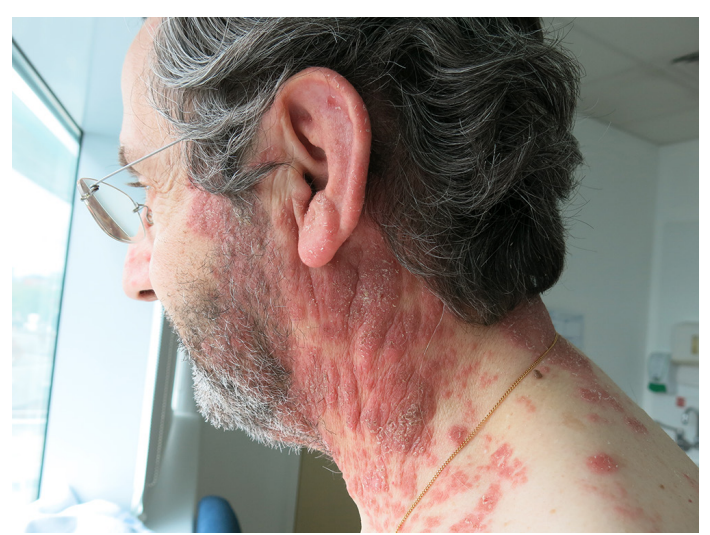

Figure 1 Vesicular plaque located to C2/3 dermatome.

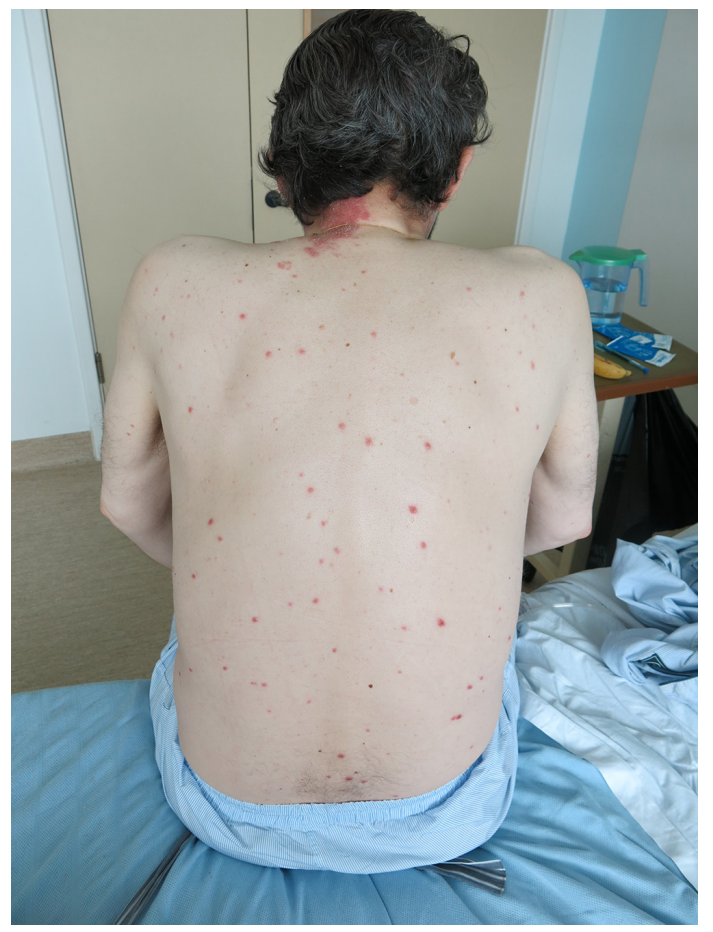

Figure 2 Disseminated vesiculopapular lesions. resembling varicella zoster virus (VZV) infection (figure 2).

Vesicular fluid from both rashes was positive for VZV on Fast Track Diagnostic multiplex real-time PCR assay, which has a specificity of $100 \%$ and sensitivity of $100 \%$ to $10^{3}$ copies $/ \mathrm{mL}$ dilution. Other methods of detection include directly with viral isolation and culture, detection of antigen in cell specimens, visualisation via light microscopy with Tzanck smears or electron microscopy or indirectly with western blotting or IgG detection. ${ }^{1}$ Further samples were sent for bacterial and fungal microscopy, culture and sensitivity to investigate bacterial or fungal infections as possible differential diagnoses, which were negative. Treatment with intravenous aciclovir resulted in clinical remission.

VZV presents with two clinically distinct forms of disease: primary vesicular lesions (chickenpox) and secondary reactivation of $\mathrm{HZ}$, in a restricted dermatomal vesicular patches or plaques (shingles). ${ }^{2}$ It is thought that all $\mathrm{HZ}$ is associated with viraemia, which immunocompromised patients cannot control. ${ }^{3}$

\section{Learning points}

- Two manifestations of VZV exist; disseminated (chickenpox) and localised (shingles).

- Immunocompromised patients are unable to control viraemia and can develop disseminated VZV.

Contributors Sole contributor.

Competing interests None declared.

Patient consent Obtained.

Provenance and peer review Not commissioned; externally peer reviewed.

(c) BMJ Publishing Group Ltd (unless otherwise stated in the text of the article) 2017. All rights reserved. No commercial use is permitted unless otherwise expressly granted.

\section{REFERENCES}

1 Singh A, Preiksaitis J, Ferenczy A, et al. The laboratory diagnosis of herpes simplex virus infections. Can J Infect Dis Med Microbiol 2005; 16:92-8.

2 Bollea-Garlatti ML, Bollea-Garlatti LA, Vacas AS, et al. Clinical characteristics and outcomes in a population with disseminated herpes zoster: a retrospective cohort study. Actas Dermosifiliogr 2017;108:145-52.

3 Gomez E, Chernev I. Disseminated cutaneous herpes zoster in an immunocompetent elderly patient. Infect Dis Rep 2014;6:5513. 
Copyright 2017 BMJ Publishing Group. All rights reserved. For permission to reuse any of this content visit http://group.bmj.com/group/rights-licensing/permissions.

BMJ Case Report Fellows may re-use this article for personal use and teaching without any further permission.

Become a Fellow of BMJ Case Reports today and you can:

- Submit as many cases as you like

- Enjoy fast sympathetic peer review and rapid publication of accepted articles

Access all the published articles

- Re-use any of the published material for personal use and teaching without further permission

For information on Institutional Fellowships contact consortiasales@bmjgroup.com

Visit casereports.bmj.com for more articles like this and to become a Fellow 